\title{
Failure mode of deteriorated concrete tunnel sections under subsidence and localised shear
}

Hiroaki Aoki MEng

PhD candidate, Department of Civil Engineering, Yokohama National

University, Yokohama, Japan; Engineer, Tokyo Electric Power Services Co. Division of PS Engineering Solution, Tokyo, Japan

(Orcid:0000-0002-0708-8207)

\section{Shu Fan BEng}

Graduated student, Department of Civil Engineering, Yokohama National University, Yokohama, Japan (Orcid:0000-0001-9761-9157)

\section{Yuto Yamanoi MEng}

Former Graduate student, Department of Civil Engineering, Yokohama National University, Yokohama, Japan; Researcher, Central Research Institution of Electric Power Industry, Structural Engineering Sector, Chiba, Japan (Orcid:0000-0001-7270-1357)
Mingqian Ren $\mathrm{BE}, \mathrm{PhD}$

Engineer, Tokyo Electric Power Services Co., Division of PS Engineering Solution, Tokyo, Japan (Orcid:0000-0002-2744-7748)

Hideaki Takahashi Dr.Eng

Manager, Tokyo Electric Power Services Co., Division of PS Engineering Solution, Tokyo, Japan (Orcid:0000-0003-1842-2095)

\section{Koichi Maekawa PhD}

Professor Emeritus, The University of Tokyo, Tokyo, Japan; Professor, Department of Civil Engineering, Yokohama National University, Yokohama, Japan (Orcid:0000-0002-4992-3004) (corresponding author: maekawa-koichi-tn@ynu.ac.jp)

It is frequently reported that groundwater containing salt flowing into underground reinforced concrete structures results in steel reinforcement corrosion. However, little has been done to study the impact of such chloride-induced deterioration on structural performance when an external load acts on the underground structure, such as ground subsidence or the movement related to faults. In this study, structural experiments and finite-element analysis of the interaction between an underground structure and the ground were undertaken to clarify the failure modes and verify the numerical analysis. The failure behaviour of an underground structure with corroded steel subject to ground displacements was then examined analytically. It is concluded from the study that chloride-induced deterioration can impair the durability of an underground structure, making it difficult to maintain the inner space, and the failure mode is related to the location of the steel corrosion, which can change the direction of the shear zone in the peripheral ground.

\section{Notation}

$\begin{array}{ll}c & \text { cohesion }\left(\mathrm{kN} / \mathrm{m}^{2}\right) \\ D & \text { diameter of each member }(\mathrm{mm}) \\ L & \text { length of each member }(\mathrm{m}) \\ R & \text { corrosion rate }(\%) \\ t & \text { thickness of each member }(\mathrm{mm}) \\ w & \text { mass of sound steel bars before corrosion }(\mathrm{mg}) \\ w^{\prime} & \text { mass of corroded steel bars excluding rust }(\mathrm{mg}) \\ \rho_{\mathrm{d}} & \text { dry density of ground }\left(\mathrm{g} / \mathrm{cm}^{3}\right) \\ \sigma_{X X} & \text { stress in XX direction }(\mathrm{kPa}) \\ \phi & \text { friction angle (degrees) } \\ \omega_{\mathrm{n}} & \text { moisture ratio of ground }(\%)\end{array}$

\section{Introduction}

Short-term settlement caused by over-pumping of groundwater or long-term settlement occurring naturally is likely to lead to a shield tunnel in the ground having to bear heavy loads. In urban areas, with many underground structures, the effects of land subsidence can cause major changes in both the stress and strain fields of the surrounding soil foundation (Castaldo and De Iuliis, 2014; Castaldo et al., 2013; Maekawa et al., 2016). As shown in Figure 1, it has been reported that a reinforced concrete (RC) tunnel buried in soft clay ground cracked in the axial direction and reduced the inner space (Oka, 2015). In this case of deformation, it was considered that the surrounding ground had been locally compacted due to leakage of water and an apparent vertical earth pressure increment (Yamazaki et al.,
2004). In addition, the groundwater flowing into the tunnel contained a large amount of chloride ions, which caused salt corrosion of the steel. The inner space kept decreasing from 2003 to 2014, so reinforcement was added to restrain any further internal displacement. In predicting the residual amount of steel due to the damage by salt, however, corrosion and age were assumed to have a linear relationship.

When earthquakes linked to active faults occur, the fault displacement caused by the fault motion may cause serious damage to civil infrastructure (Sakurai, 1990). Typical cases of damage occurring during the collapse of the Ishioka dam during the Chi-Chi earthquake in Taiwan (Omachi, 2000) and damage to the Uonuma tunnel during the Niigata Chuetsu earthquake (Konagai, 2005; Mori, 2013) have been reported. In Japan, where there are many active faults, it is difficult to avoid faults during construction. Thus, it is necessary to establish a reliable analysis method for the fault displacement problem. By introducing strain softening into the soil model, the localised shear behaviour of the ground due to fault displacement can be well simulated (Soltani and Maekawa, 2015). With this soil model, sensitivity analysis was performed by using the initial velocity of the fault displacement and the soil rigidity as the analysis parameters, which confirmed the applicability of soil-structure coupled non-linear analysis of the fault displacement problem (Funaba et al., 2018). So far, studies of the fault displacement problem for some important structures, such as nuclear power plants, have been 


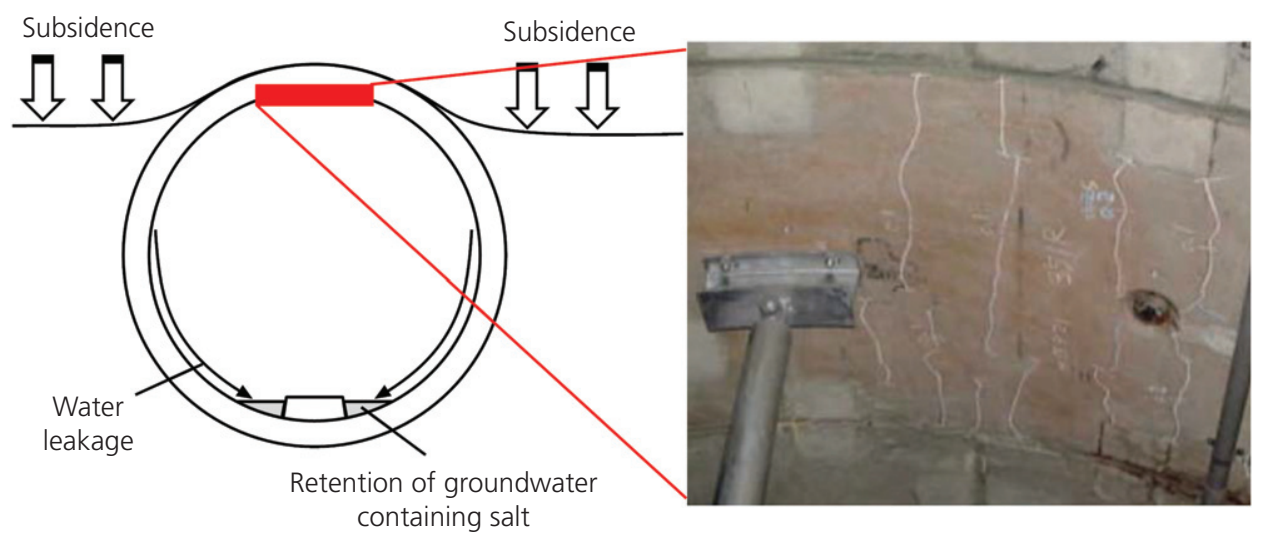

Figure 1. Damaged circular shield tunnel

conducted (Higuchi et al., 2017; Otsuka et al., 2012; Sakashita and Hata, 2019; Towhata and Ishihara,1985), but few studies have focused on structures undergoing material degradation.

The purpose of the present study is to assess the safety and serviceability performance of underground RC tunnels and ducts in consideration of the soil kinetics with subsidence and the propagating shear band of the soil foundation. In this study, first, a series of small-scale experiments (specimen outer diameter $200 \mathrm{~mm}$ ) was conducted, through which the effect of material deterioration was examined. Then a medium-scale experiment and its corresponding simulation (specimen outer diameter $1050 \mathrm{~mm}$ ) were performed, which verified the validity of the numerical analysis. Finally, through numerical analysis (software DuCOM-COM3), the analytical models of an underground $\mathrm{RC}$ tunnel and an underground $\mathrm{RC}$ duct were examined and the impact of the degree and location of chloride-induced deterioration on the failure mode was studied with a view to rational maintenance planning in the future (Aoki et al., 2019).

\section{Structural experiment of RC tunnel with $1 / 20$ scale}

2.1 Experimental method of RC tunnel with $1 / 20$ scale structure

Two small-scale RC tunnel specimens with internal diameter $157 \mathrm{~mm}$ and outer diameter $200 \mathrm{~mm}$, and a width of $50 \mathrm{~mm}$, were cast using mortar; this represents around $1 / 20$ of the actual structure. The strength of the mortar was $40 \mathrm{~N} / \mathrm{mm}^{2}$ (at 28 days). The wire mesh was reinforced into each specimen with a reinforcement ratio of $0.71 \%$. One specimen was the sound case, without damage to the wire mesh, and the other was the damaged case, with no wire mesh in the top quarter of the specimen, so as to reproduce the occurrence of steel corrosion around the floor-path slabs of tunnel.

Before loading the mortar specimens, a rigid soil box $(450 \times 680 \times 600 \mathrm{~mm})$ was filled with sand (as shown in
Figure 2(a)). The sand was poured into the box and compacted in layers to reach a density of about $1.74 \mathrm{~g} / \mathrm{cm}^{3}$. Then $80 \%$ of the height of the specimen was buried in soil and displacementcontrolled monotonic loading was applied directly at the top of the RC tunnel exposed to air, with the aim of reproducing the effect of ground subsidence on tunnels in reality. Loading was stopped when the forced displacement reached $25 \mathrm{~mm}$. Four strain gauges were pasted on the interior surface (top and bottom), as well as the exterior surface (left and right) of specimens, where bending cracks were expected to be generated.

\subsection{Experimental result}

Figure 2(b) compares the load-displacement relationship obtained experimentally at the top of the two specimens. The peak load of the sound case and the damaged case is $1.79 \mathrm{kN}$ and $1.42 \mathrm{kN}$, respectively, which indicates that loss of reinforcement plays a rather negative role in the capacity of the RC tunnel. After the first peak load, the load falls sharply in both cases due to cracking in the structure members. At the same time, the measured value by the strain gauges at four positions shows a sharp increase. Then, the load remains flat in the sound case, but gradually rises again in the damaged case, showing that the ultimate limit state of RC underground members does not necessarily coincide with the ultimate capacity of soil-RC interacting systems.

The second rapid fall in load is considered to be the shear failure of soil around the RC tunnel in both cases, as the clearly apparent bulging on the bilateral soil face was present at the same displacement; this means that the failure of dense sand had occurred, accompanied by the appearance of a failure surface and considerable bulging of a sheared mass of sand. For the damaged specimen, a $21.6 \mathrm{~kg}$ weight was added to the side soil surface before loading to restrain the bulging, so as to replicate the actual ground conditions more closely. Although the bulging still occurred, after the load decreased from the second peak, the load increased slightly and kept at a high level compared with the sound case without additional weight on the soil surface. 


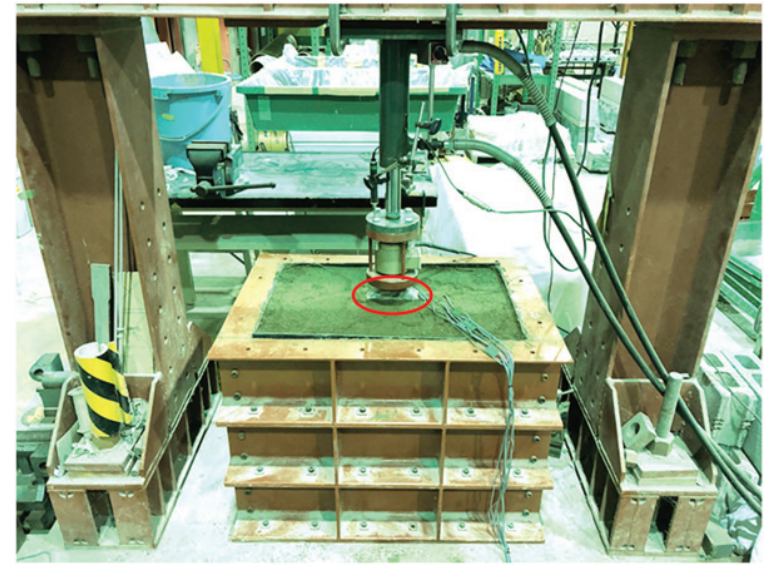

(a)

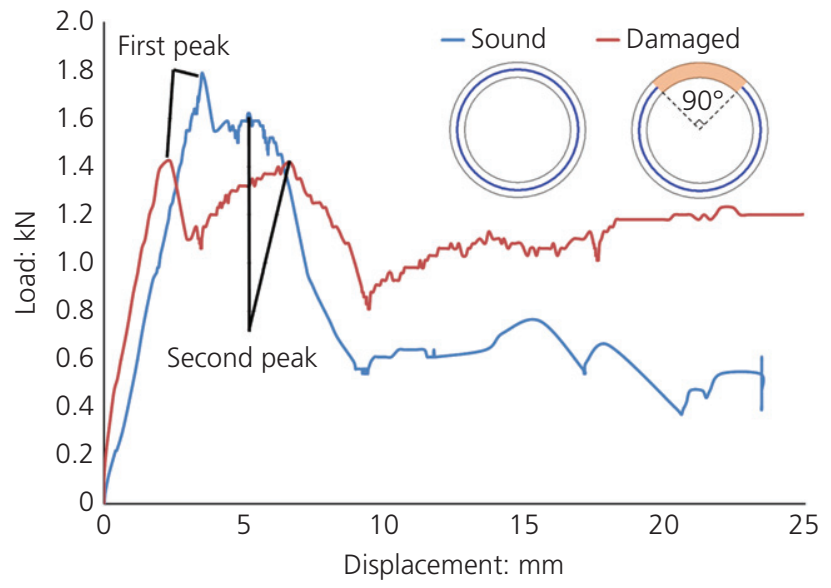

(b)

Figure 2. Outline of small-scale experimental equipment: (a) experimental equipment; (b) load-displacement relationship
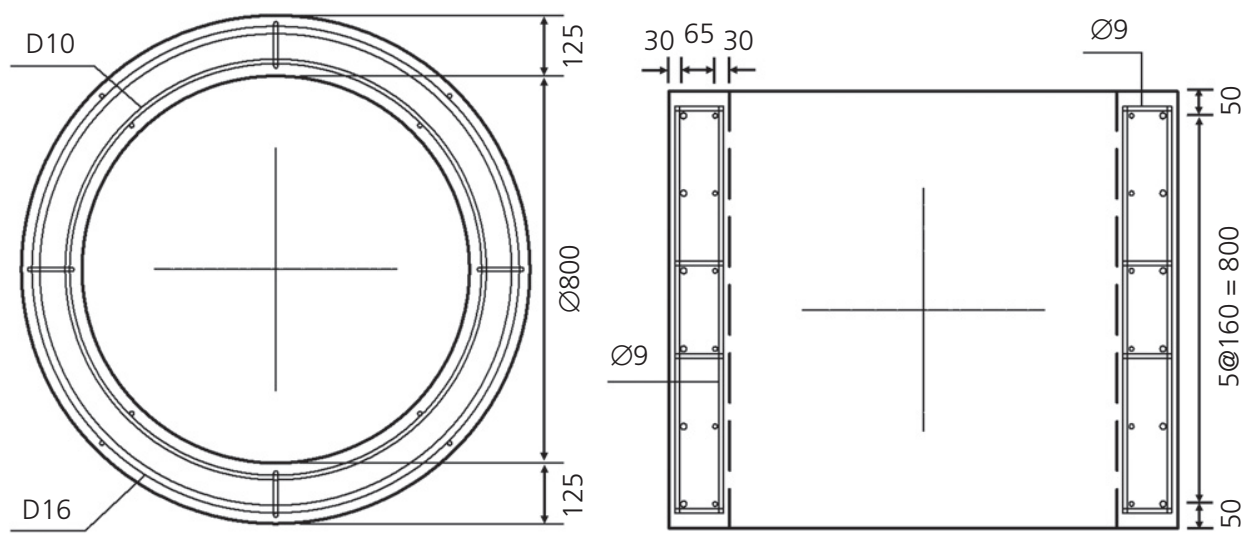

Figure 3. Specimen drawing (unit: $\mathrm{mm}$ )

Furthermore, when inspecting the crack pattern and damage condition of the two RC tunnels after loading, sliding shear along the bending crack was clearly observed at the side in each case. This indicates that there is a risk of sliding shear caused by the unequal lateral earth pressure from ground subsidence, regardless of whether the reinforcement is corroded or not. It is worth noting that once sliding shear along the bending crack occurs in an underground RC structure, the compression zone cannot be sustained, so a great inflow of underground water is expected to occur.

\section{Structural experiment of RC tunnel with $1 / 4$ scale}

\subsection{Experimental method of RC tunnel with $1 / 4$ scale structure}

The specimen used in the experiment was an integrated circular RC tunnel with diameter of $1050 \mathrm{~mm}, 125 \mathrm{~mm}$ thick and $900 \mathrm{~mm}$ wide; this represents $1 / 4$ of the actual structure, as shown in Figure 3. In order to keep the same reinforcement ratio as the actual structure, the outside and inside of the tunnel incorporated an arrangement of six main steel bars with $10 \mathrm{~mm}$ dia. and $160 \mathrm{~mm}$ pitch, respectively. The yield strength of the steel bar was $295 \mathrm{~N} / \mathrm{mm}^{2}$. The mix proportion of the concrete is shown in Table 1 , and the strength of concrete on the day of the experiment was $44.8 \mathrm{~N} / \mathrm{mm}^{2}$ (at 72 days).

Figure 4 shows the design drawing and photograph of the experimental equipment. The experiment was conducted on a site ground. To avoid the impact of excessive subsidence of the ground, some ground improvement was carried out in advance, where a steel pile $216 \mathrm{~mm}$ dia. $\times 12.7 \mathrm{~mm}$ was piled first and a steel plate of $2000 \times 2000 \times 800 \mathrm{~mm}$ was placed on top of the pile, then a $500 \mathrm{~mm}$ thick sand layer was formed between the specimen and the steel plate. The RC tunnel was set in a steel formwork placed on the ground, and the surroundings of the 
Table 1. Mix proportion of the concrete

\begin{tabular}{|c|c|c|c|c|c|c|c|c|}
\hline \multirow{2}{*}{$\begin{array}{l}\text { Slump: } \\
\mathrm{cm}\end{array}$} & \multirow{2}{*}{$\begin{array}{c}\text { Air } \\
\text { content: } \%\end{array}$} & \multirow{2}{*}{$\begin{array}{c}\text { Water-to-cement } \\
\text { ratio, } \\
\text { W/C: \% }\end{array}$} & \multirow{2}{*}{$\begin{array}{c}\text { Sand } \\
\text { percentage, } \\
\text { s/a: } \%\end{array}$} & \multicolumn{4}{|c|}{ Unit quantity: $\mathrm{kg} / \mathrm{m}^{3}$} & \multirow{2}{*}{$\begin{array}{c}\text { Admixture } \\
\text { CA }\end{array}$} \\
\hline & & & & Water W & Cement C & Fine aggregate $S$ & Coarse aggregate $\mathrm{G}$ & \\
\hline 18 & 2 & 65 & 60 & 185 & 285 & 1121 & 750 & 3.27 \\
\hline
\end{tabular}
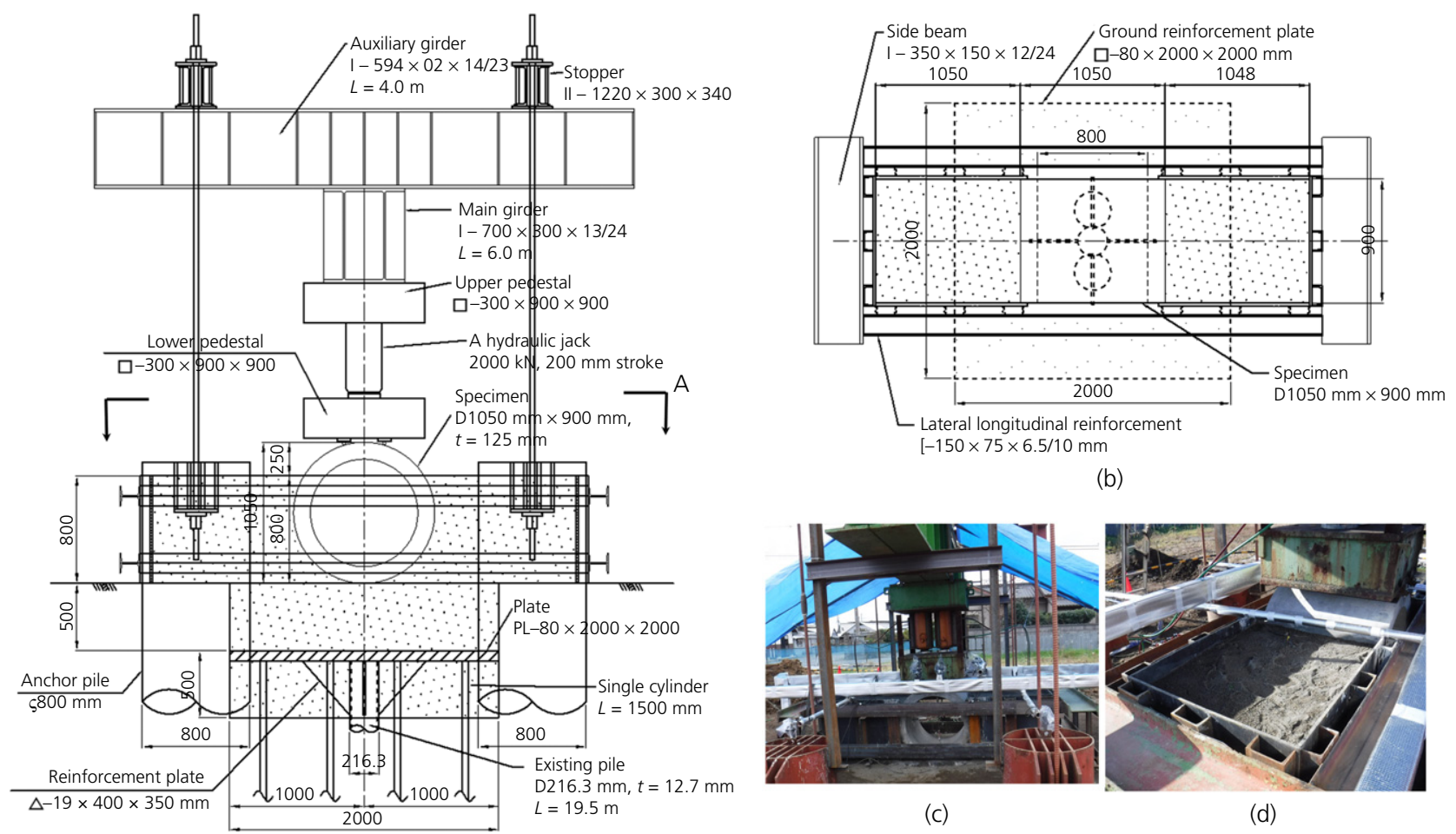

(b)

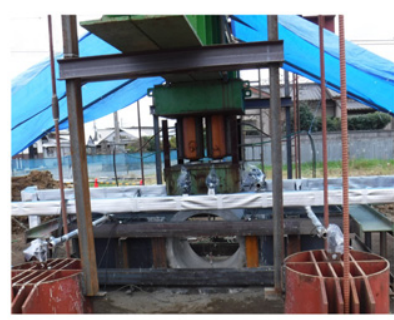

(c)

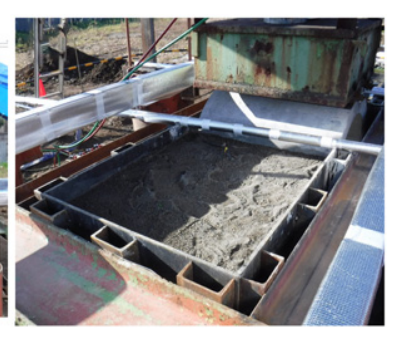

(d)

(a)

Figure 4. Outline of experimental equipment: (a) drawing; (b) top view at A-A; (c) photograph of the experimental equipment; (d) inside the steel frame

tunnel were filled with sand. Approximately $80 \%$ of the specimen was buried in the ground and the rest was exposed from the ground. Thus, the lateral pressure and supporting action of soil on the RC tunnel is considered. The physical properties of the sand were obtained as shown in Table 2 .

The loading method was two-point line loading with a space of $300 \mathrm{~mm}$. The loading was carried out by multi-stage cyclic loading and continued until the test specimen was destroyed. At the same time, the vertical and horizontal inner space displacements of the tunnel and the earth pressure at the bottom and side of the specimen were measured, as shown in Figure 5.

Table 2. Physical properties of artificial ground

\begin{tabular}{lccc}
$\begin{array}{c}\text { Dry density, } \\
\boldsymbol{\rho}_{\mathrm{d}}: \mathbf{g} / \mathbf{c m}^{3}\end{array}$ & $\begin{array}{c}\text { Moisture ratio, } \\
\omega_{\mathbf{n}}: \%\end{array}$ & $\begin{array}{c}\text { Cohesion, } \\
\mathbf{c}: \mathbf{k N} / \mathbf{m}^{2}\end{array}$ & $\begin{array}{c}\text { Friction angle, } \\
\phi: \text { degrees }\end{array}$ \\
\hline 1.514 & 12.1 & 7.1 & 33.7 \\
\hline
\end{tabular}

\subsection{Analytical method}

The RC constitutive law that was used consists of the constitutive relation of the concrete and the reinforcement covered by the concrete. A non-linear three-dimensional constitutive law that can consider distributed fixed cracking in up to six directions has been developed (Maekawa and Fukuura, 2013), and the behaviour of concrete before and after cracking is considered separately. Before the concrete cracks, the elasto-plastic fracture model law of uncracked concrete is applied; after the concrete cracks, the transfer characteristics of shear, compression and tension behaviour of the crack plane are combined.

The analysis program is based on the Newton-Raphson method; at any iteration, the stiffness matrix is renewed and decomposed. The convergence criterion is that the norm of the nodal disequilibrium force is less than $1 \%$ of the total nodal force increment. 


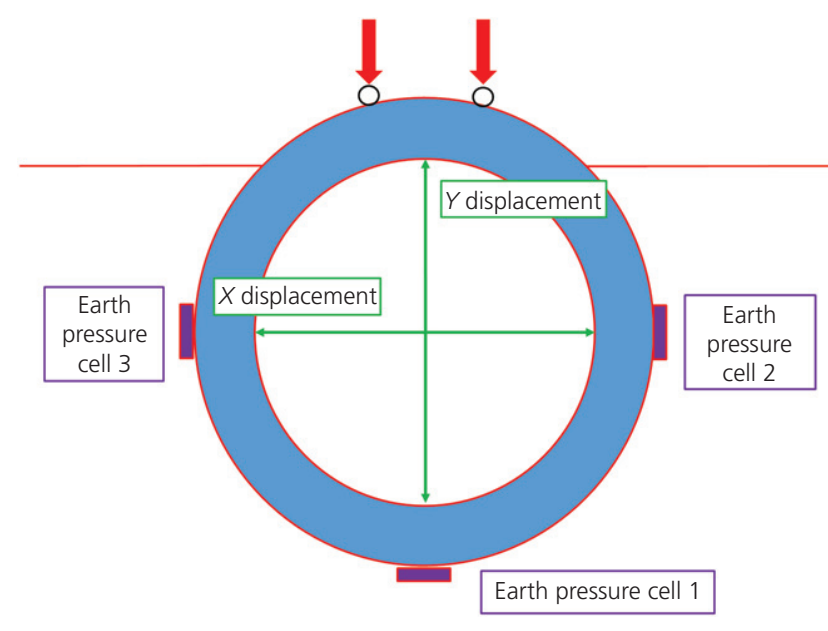

Figure 5. Measurement point of specimen

The corrosion mass ratio $\left(\mathrm{g} / \mathrm{cm}^{2}\right)$ per unit surface area of the steel is given for the elements in the area where corrosion is considered. The corrosion rate is calculated from the difference between the weight of sound steel bars before corrosion and the weight of steel with corrosion products removed by the following equation.

$$
R=\left(w-w^{\prime}\right) / w \times 100
$$

With the numerical analysis method, the decrease in the reinforced steel cross-section associated with steel corrosion, as well as the decline in the adhesive effect of the concrete could be quantified (Toongoenthong and Maekawa, 2005).

Previous studies have suggested that numerical and theoretical models are always affected by modelling uncertainties that may have an influence on the structural resistance (Castaldo et al., 2019, 2020; Celarec and Dolšek, 2013; Holický et al., 2016). In this study, the authors first intend to verify the range of influence of the land subsidence and the direction of fault displacement. Thus, to meet the challenge, the deterministic approach was selected. Hereafter, the authors would like to discuss the uncertainty of the numerical model as the next step. To clarify the damage to buried structures, timedependent features of the ground such as liquefaction and consolidation are fictitiously converted to forced displacements and boundary conditions of the ground with a deterministic approach.

\subsection{Numerical modelling}

As shown in Figure 6, the numerical model of the mediumscale experiment consists of the tunnel, sand layer and the steel plate. A three-dimensional isoperimetric hexahedron solid element with eight gauss points was applied and a single layer in the depth direction for both the tunnel and ground was composed. At the interface, the soil element and concrete element share nodes. The tunnel structure was composed of the smeared RC element and the plain concrete (PL) element, and the main reinforcement was set in the RC element in the circumferential direction ( $X, Z$ directions). The steel plate element is set to be elastic.

Tables 3 and 4 show the physical properties of the ground and the structure, respectively. The physical properties of the sand ground were obtained from the triaxial test results, and the properties of the clay ground were determined by back-estimation of the preloading test. Consistently with the experiment, a two-point loading with a forced displacement interval of $0.03 \mathrm{~cm} / \mathrm{step}$ was applied. The support of the pile and ground, as well as the lateral restraint of steel formwork, were modelled as the boundary here. In detail, the nodes of the pile supporting area are constrained in the $Z$ direction, while the boundary of the sandy ground was constrained in the symmetric direction.

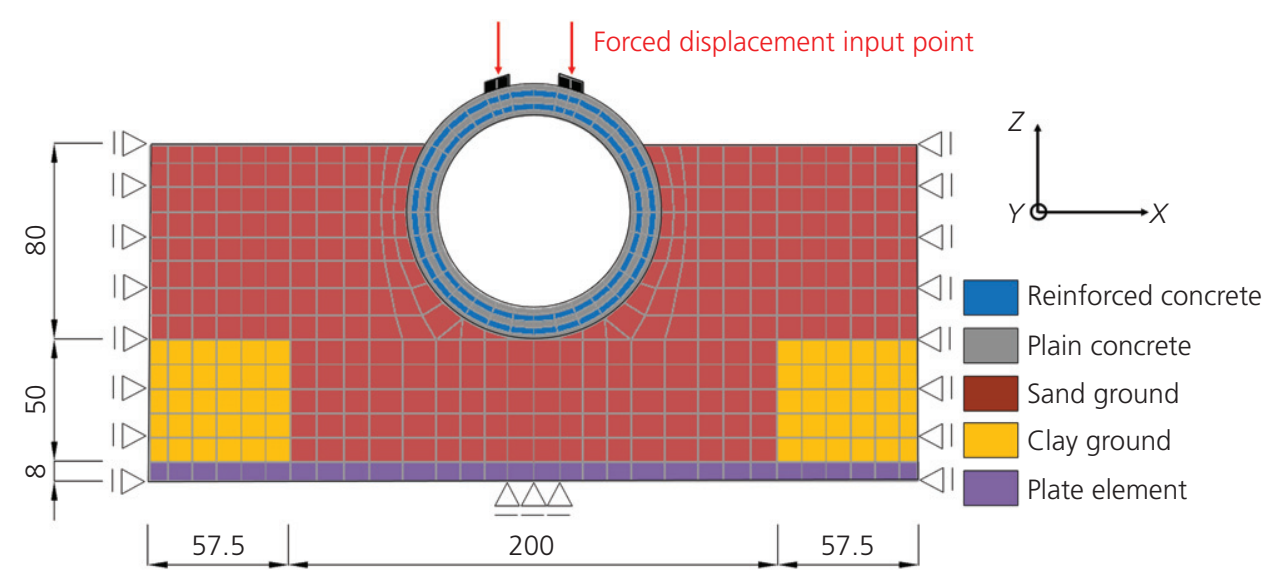

Figure 6. Analytical model for medium-scale experiments 
Table 3. Physical properties for numerical analysis of structural experiments (ground)

\begin{tabular}{lccccccc} 
Item & $\begin{array}{c}\text { Initial shear } \\
\text { stiffness: MPa }\end{array}$ & $\begin{array}{c}\text { Shear } \\
\text { strength: } \mathbf{M P a}\end{array}$ & $\begin{array}{c}\text { Weight per unit } \\
\text { volume: } \mathbf{k g f / \mathbf { c m } ^ { 3 }}\end{array}$ & $\begin{array}{c}\text { Relative } \\
\text { density: \% }\end{array}$ & $\begin{array}{c}\text { Cohesive } \\
\text { strength: MPa }\end{array}$ & $\begin{array}{c}\text { Friction } \\
\text { angle: deg }\end{array}$ & $\begin{array}{c}\text { Shear } \\
\text { zone: } \mathbf{c m}\end{array}$ \\
Clay & 60 & 0.5 & 0.00175 & 50 & 0.05 & 5.0 & 0.5 \\
Sand & 170 & 5 & 0.00151 & 50 & 0.0071 & 33.7 & 0.5 \\
\hline
\end{tabular}

Table 4. Physical properties for numerical analysis of structural experiments (RC structure)

\begin{tabular}{lccccc|} 
Item & $\begin{array}{c}\text { Young's modulus: } \\
\text { MPa }\end{array}$ & $\begin{array}{c}\text { Compressive strength: } \\
\mathbf{M P a}\end{array}$ & $\begin{array}{c}\text { Tensile strength: } \\
\text { MPa }\end{array}$ & $\begin{array}{c}\text { Poisson's } \\
\text { ratio }\end{array}$ & $\begin{array}{c}\text { Weight per unit volume: } \\
\mathbf{k g f} / \mathbf{c m}^{\mathbf{3}}\end{array}$ \\
\hline Concrete & 28000 & 45.7 & 1.4 & 0.2 & 0.0025 \\
Steel & 210000 & - & - & 0.2 & 0.0025
\end{tabular}

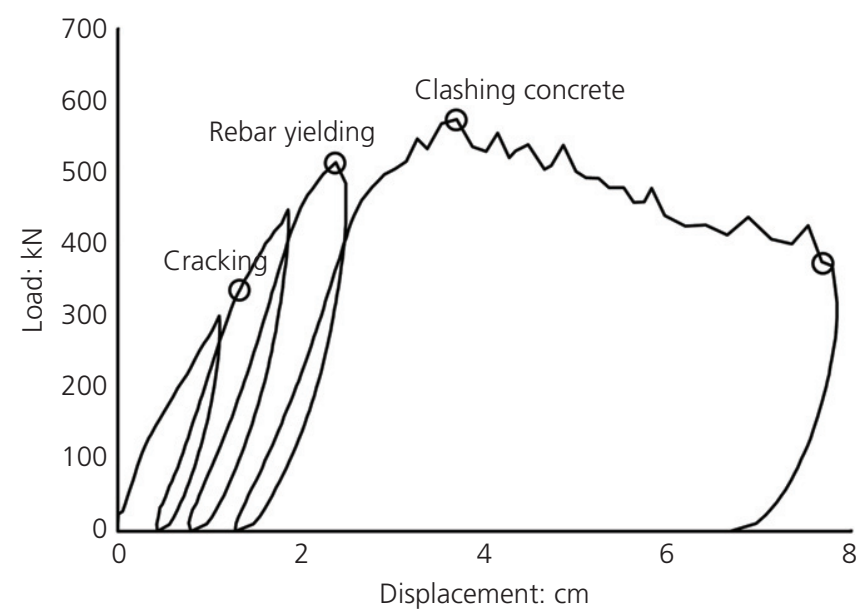

(a)

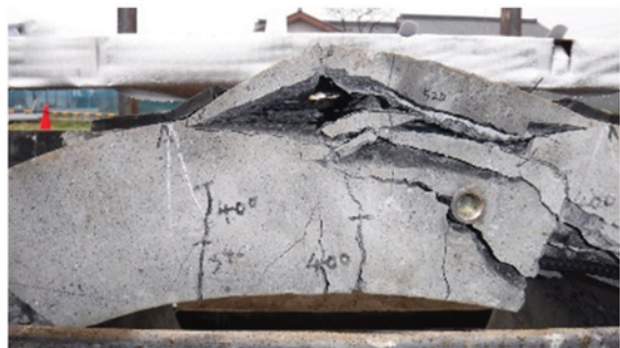

(c)

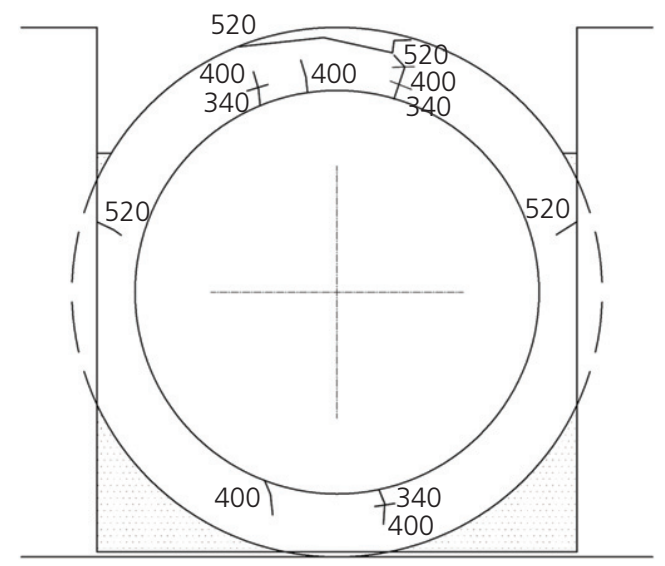

(b)

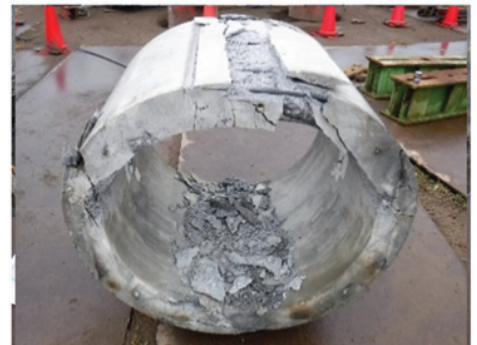

(e)

Figure 7. Results of the experiment: (a) load-displacement relationship; (b) crack pattern (load level: 520 kN); (c) neighbourhood of loading point; (d) top and sides part; (e) specimen after loading

3.4 Experimental results and numerical analysis results The results of the experiment are shown in Figure 7. The load-displacement relationship (as shown in Figure 7(a)) progressed linearly up to $520 \mathrm{kN}$, then the curvature changed greatly and reached the maximum load of $570 \mathrm{kN}$. It can be speculated that the inner rebars at the top and bottom of the tunnel yielded at the load level of $520 \mathrm{kN}$, and the outer concrete at the top and the inner concrete on the side collapsed at a load level of $570 \mathrm{kN}$. At the load level of $340 \mathrm{kN}$, cracks first occurred in the depth direction on the top and bottom of the inner surface. Then cracks gradually extended outward and widened as the load increased. When the load level was $520 \mathrm{kN}$, a circumferential crack was generated from the outer edge of the upper part of the specimen, and a crack in the thickness direction was observed on the side surface of the specimen, as shown in Figure 7(b). Figures 7(c)-7(e) show the states of the specimen after loading. As the specimen deformed greatly at the position where the side cracks occurred, it can be 
seen that the deformation after the maximum load advanced with the side of the specimen as a hinge.

Figure 8 shows the comparison of experiment and analysis in the load-displacement relationship. The numerical analysis is in good agreement with the experiment in both initial stiffness and maximum load, with high accuracy. Regarding the toughness after the maximum load, the generally declining behaviour of load owing to the support of the ground can also be roughly reproduced. Figure 9 shows the strain and deformation diagram at the maximum load. Shear failure occurred in the ground from the tunnel surround to the lower boundary. Figure 10 shows a comparison of stress of the earth pressure between the experiment and the numerical analysis. The numerical analysis showed higher lateral earth pressure than

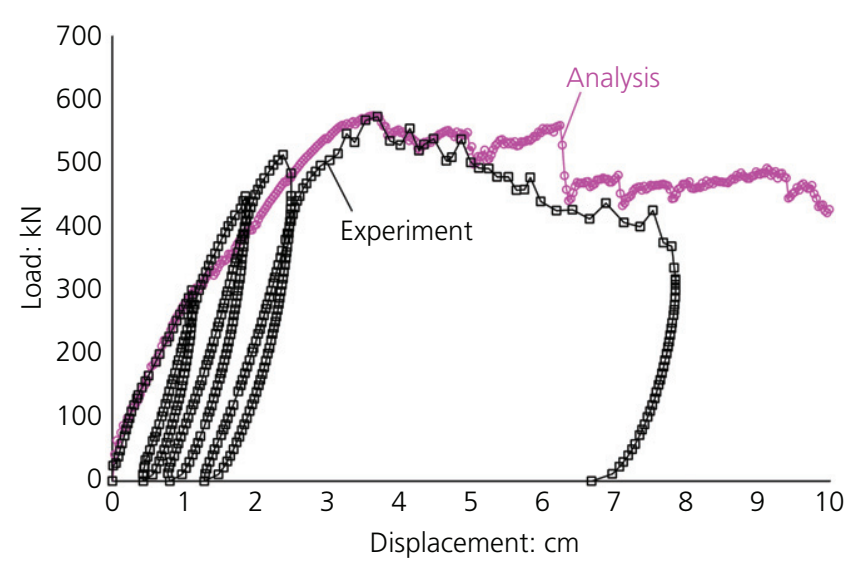

Figure 8. Comparison of load-displacement relationship between experiment and numerical analysis the experiment, but it was still able to reproduce the experiment at the initial load level. The earth pressure cell in the vertical direction is not described because of a malfunction.

Figure 11 shows the comparison of the crack properties of the specimen and the inner space displacement. The principal strain of the analysis rapidly increased from $340 \mathrm{kN}$ to $520 \mathrm{kN}$ on the top and bottom of the inner surface and to the left and right of the outer surface. Then the specimen reached its maximum load after cracking had occurred and the main rebar had yielded. The concentration region of the principal strain is in good agreement with the crack position of the experiment. Moreover, the relationship between the inner space displacement and the load is also in agreement with the experiment. In other words, the behaviour from elastic to plastic in vertical and horizontal directions could be reproduced well. Although it is difficult to inspect the outer surface of the underground RC tunnel, the outside load state, for example the earth pressure, can be estimated using the inner space displacement as an index.

From the comparison between the numerical analysis and the experiment for the above two cases, it is found that the numerical analysis can accurately reproduce the load-displacement relationship and the inner space change process. In addition, the stiffness of the RC tunnel in a sound state did not decrease significantly after the maximum load, which indicates that the ability to maintain the inner space was retained.

\section{Numerical analysis of underground RC tunnels}

\subsection{Outline}

Based on the verified numerical analysis method, the responding behaviour of a circular shield tunnel under a ground
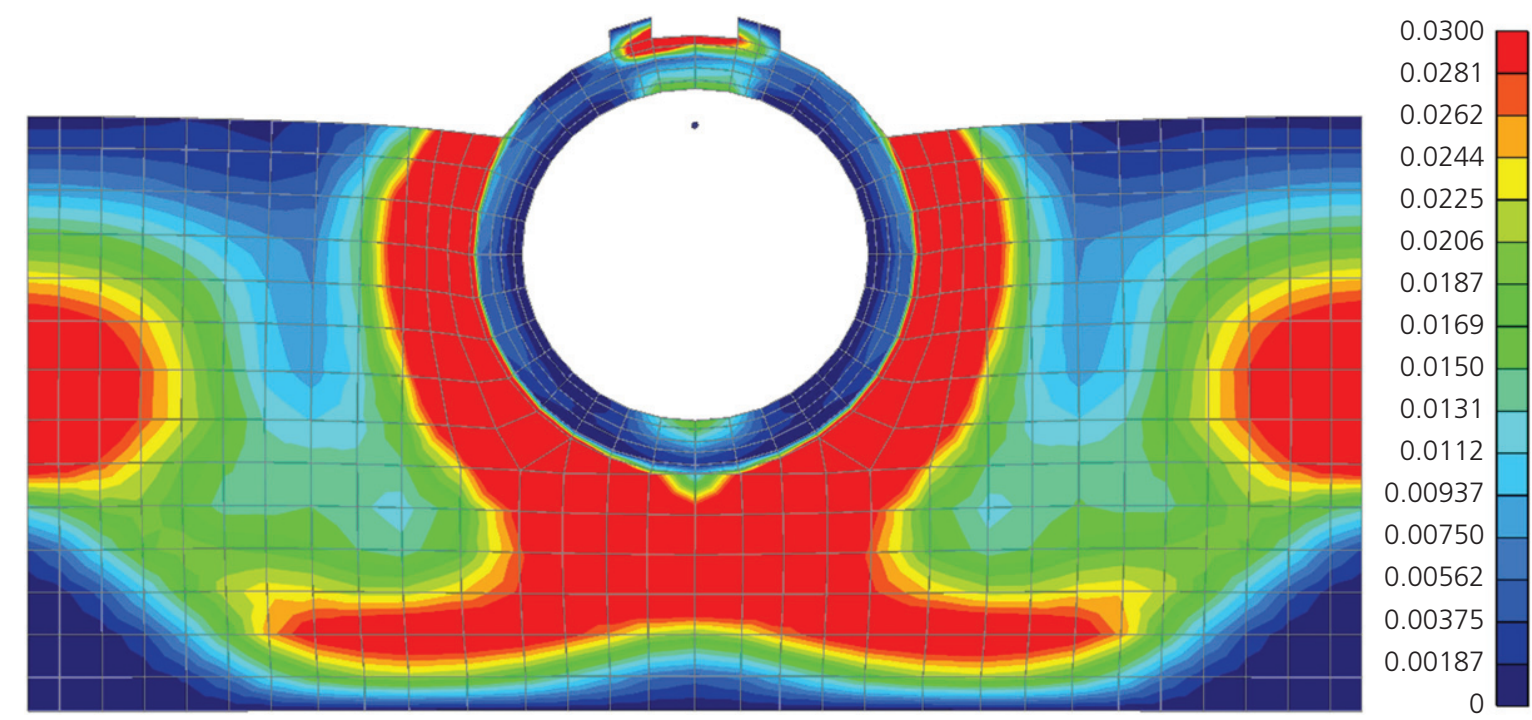

Figure 9. Diagram showing principal strain distribution and deformation at maximum load 
subsidence load condition is simulated and the impact of salt corrosion on durability is evaluated in this section. It is known that structural elements subject to high bending moment

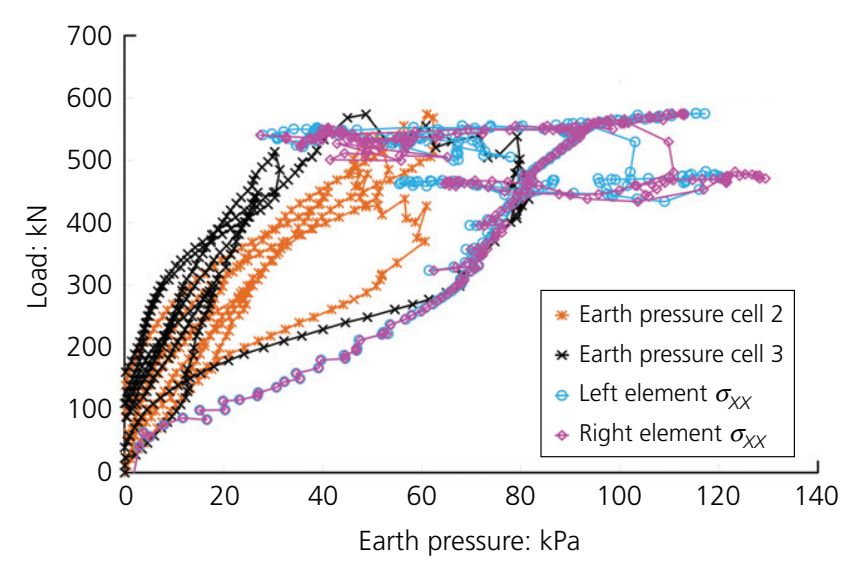

Figure 10. Comparison of stress between the earth pressure cell and the numerical analysis action (average axial force eccentricity) are affected by the deterioration action of chloride (Castaldo et al., 2017). In this study, the parameter is the existence of steel corrosion at the bottom of the shield tunnel, and the effect of salt corrosion on the durability of circular shield tunnels is investigated.

\subsection{Numerical modelling}

A circular tunnel section with an outer diameter of $4.2 \mathrm{~m}$ and a thickness of $25 \mathrm{~cm}$ was taken as the target structure, as shown in Figure 12. The analytical model comprised single-layer elements in the depth direction for both the tunnel and the ground, and the soil element and concrete element share nodes at the interface, as per the model described in Section 3. The physical properties of the ground and $\mathrm{RC}$ structure are given in Tables 5 and 6, respectively. For the ground, a soft soil that does not exhibit any softening behaviour is assumed, and a bilinear material model was assigned. The tunnel structure comprised RC elements and PL elements. For the RC elements, the main reinforcements were configured in the circumferential directions ( $X$ - and $Z$-directions) and the distributing reinforcements

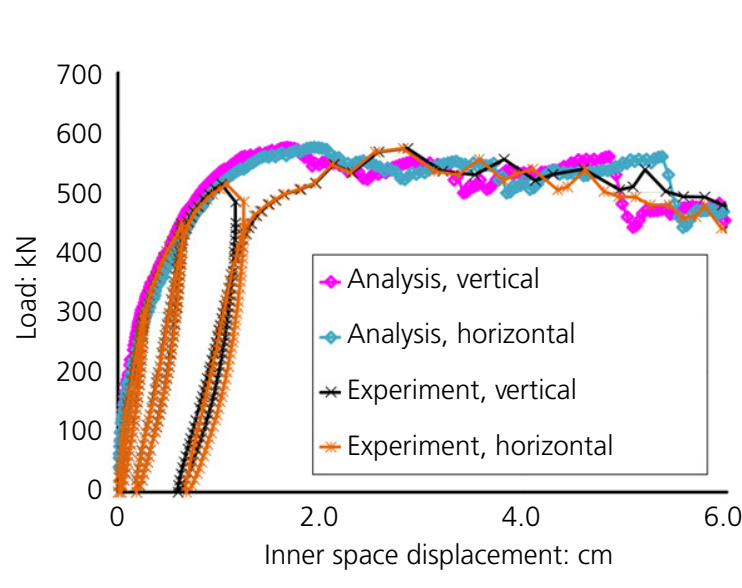

(a)

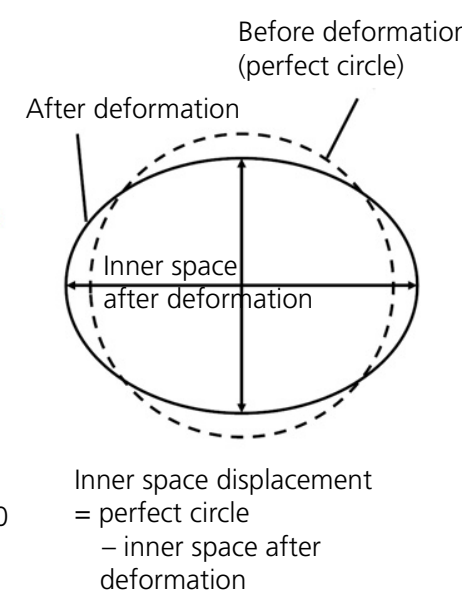

\begin{tabular}{l}
0 \\
0.00400 \\
0.00375 \\
0.00350 \\
0.00325 \\
0.00300 \\
0.00275 \\
0.00250 \\
0.00225 \\
0.00200 \\
0.00175 \\
0.00150 \\
\hline \\
\hline \\
\hline
\end{tabular}

(c)

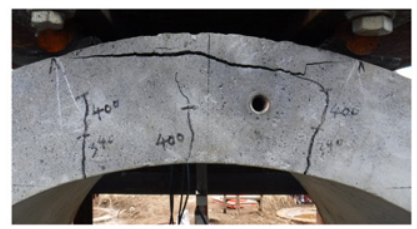

(d)

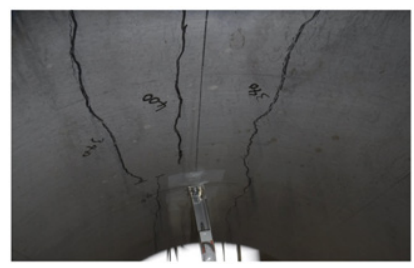

(e)

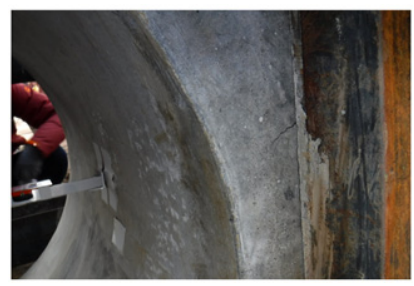

(f)

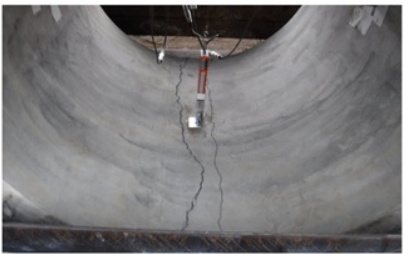

(g)

Figure 11. Comparison between experiment and analysis: (a) relationship between inner space displacement and load; (b) principal strain diagram of structure (when load level is $320 \mathrm{kN}$ ); (c) principal strain diagram of structure (when load level is $520 \mathrm{kN}$ ); (d) neighbourhood of loading point; (e) top of inside; ( $f$ ) right part of side; ( $g$ ) lower part of inside 


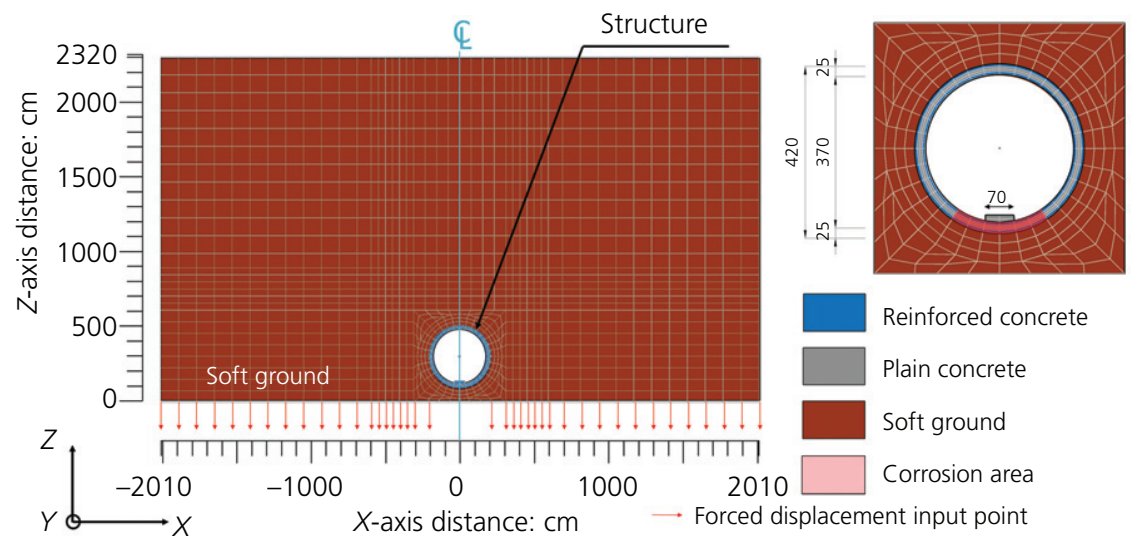

Figure 12. Overview diagram of analytical model and enlarged diagram of the shield tunnel and periphery (unit: $\mathrm{cm}$ )

Table 5. Physical properties for numerical analysis of underground tunnels subjected to ground subsidence (ground)

\begin{tabular}{lccc}
$\begin{array}{l}\text { Initial shear } \\
\text { stiffness: } \mathrm{MPa}\end{array}$ & $\begin{array}{c}\text { Shear } \\
\text { strength: } \\
\mathrm{MPa}\end{array}$ & $\begin{array}{c}\text { Weight per } \\
\text { unit volume: } \\
\mathbf{k g f} / \mathrm{cm}^{3}\end{array}$ & $\begin{array}{c}\text { Poisson's } \\
\text { ratio }\end{array}$ \\
\hline 1.86 & 0.1 & 0.00166 & 0.45 \\
\hline
\end{tabular}

were set in the axial direction ( $Y$-direction). For the purpose of reflecting the impact of corrosion, a sound case and a case of partial degradation were analysed. The region of steel corrosion is the bottom of the tunnel, as indicated in pink in Figure 12. In actual conditions, waterlogging happens easily in this area and the steel corrosion resulted from chloride-induced deterioration occurs frequently. Assuming that the corrosion deterioration is marked, the corrosion rate is assigned as $20 \%$ in accordance with experiences on the site.

To reproduce the ground subsidence, forced displacement in the $Z$-direction along the bottom boundary, except for the lower part of the structure, was imposed. After $3 \mathrm{~cm}$ of forced displacement, a corrosion procedure was applied to the target region. Then the forced displacement loading was continued.

\subsection{Analysis result}

The strain distribution and deformation of the RC tunnel and ground are shown in Figure 13. In the sound case, shear deformation of the ground was prominent around the perimeter of the shield tunnel and the maximum principal strain aggregated in the vicinity of the structure. The range of impact was relatively broad. In the degradation case, however, damage was concentrated at the location of deterioration, so that shear deformation of the peripheral ground was mitigated and the large principal strain of the ground was limited to the area near the structure.

The process of deformation and strain distribution of the RC tunnel related to settlement are shown in Figure 14. In the sound case, as the settlement increases, tensile strain concentration over $3000 \mu$ is observed and located on the side of the outer surface, as well as on the top and bottom of the inner surface, which means cracks have occurred in these areas. In the degradation case, however, the larger tensile strain concentration is localised in the region of corrosion, and the strain on the top of the inner surface as well as the side of the outer surface is smaller than the strain in the sound case. As the forced displacement increases, the strain becomes significantly concentrated in the region of steel corrosion and the inner space can no longer be maintained.

Figure 15 shows the relationship between the ground subsidence $(0-35 \mathrm{~cm})$ and the inner space displacement of the tunnel. The solid line and the dotted line represent the inner space displacement in the vertical and horizontal direction, respectively. In the degradation case, after the steel corrosion period, the vertical displacement continues to increase and the displacement in the horizontal direction ceases to change after the settlement has exceeded $15 \mathrm{~cm}$. In the sound case, the ratio of vertical and horizontal displacement is small and the performance of the inner space is maintained. In the degradation case, chloride-induced deterioration significantly reduces the tunnel performance. When the corrosion rate is $20 \%$, a settlement of $35 \mathrm{~cm}$ causes 1.5 times the vertical displacement of the sound case.

\section{Numerical analysis of underground RC ducts}

\subsection{Outline}

In assessing the interaction between an underground structure and the ground, it is important to evaluate appropriately the progression of localised shear displacement (fault) of the ground. The reason for this is that the change in rigidity of the underground structure may significantly influence the development of the direction and location of the shear zone formation. By way of a validated model capable of simulating the shear 
Table 6. Physical properties for numerical analysis of underground tunnels subjected to ground subsidence (RC structures)

$\begin{array}{lcccc}\text { Young's modulus: } \mathbf{M P a} & \text { Compressiv e strength: MPa } & \text { Tensile strength: } \mathbf{M P a} & \text { Poisson's ratio } & \text { Weight per unit volume: } \mathrm{kgf} / \mathrm{cm}^{\mathbf{3}} \\ 32000 & 15 & 2.9 & 0.2 & 0.0026\end{array}$

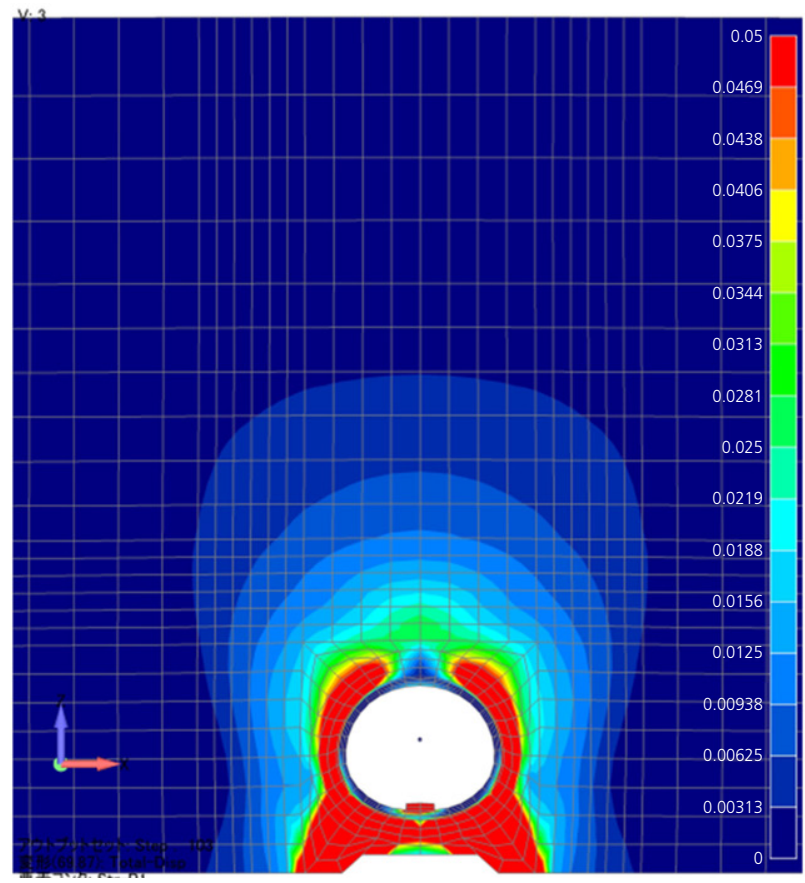

(a)

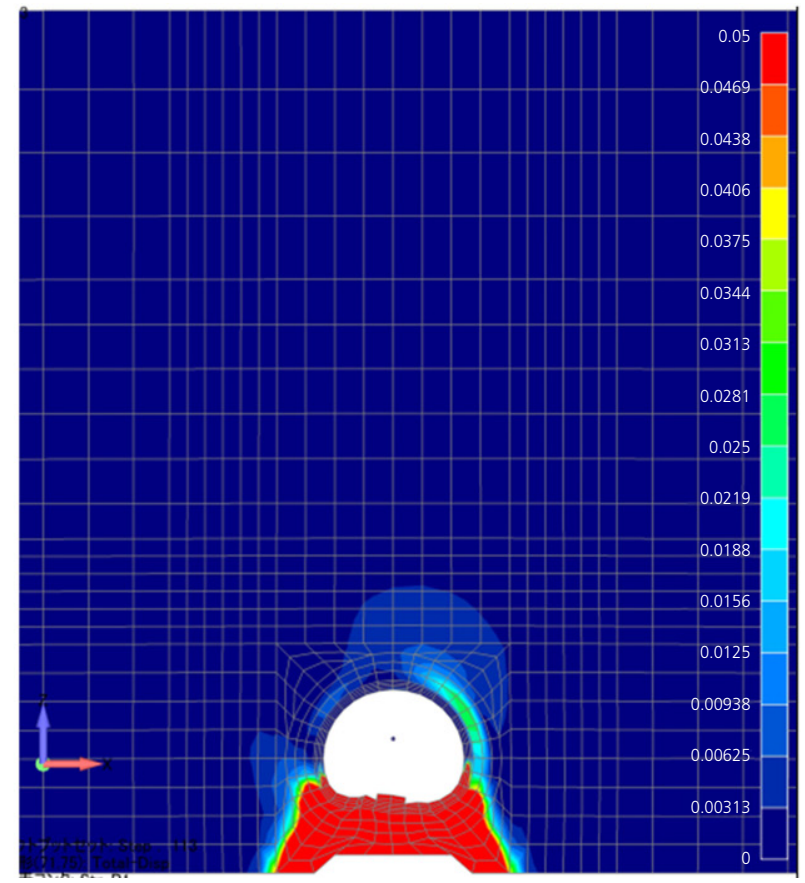

(b)

Figure 13. Diagrams showing principal strain distribution and deformation of structure and ground

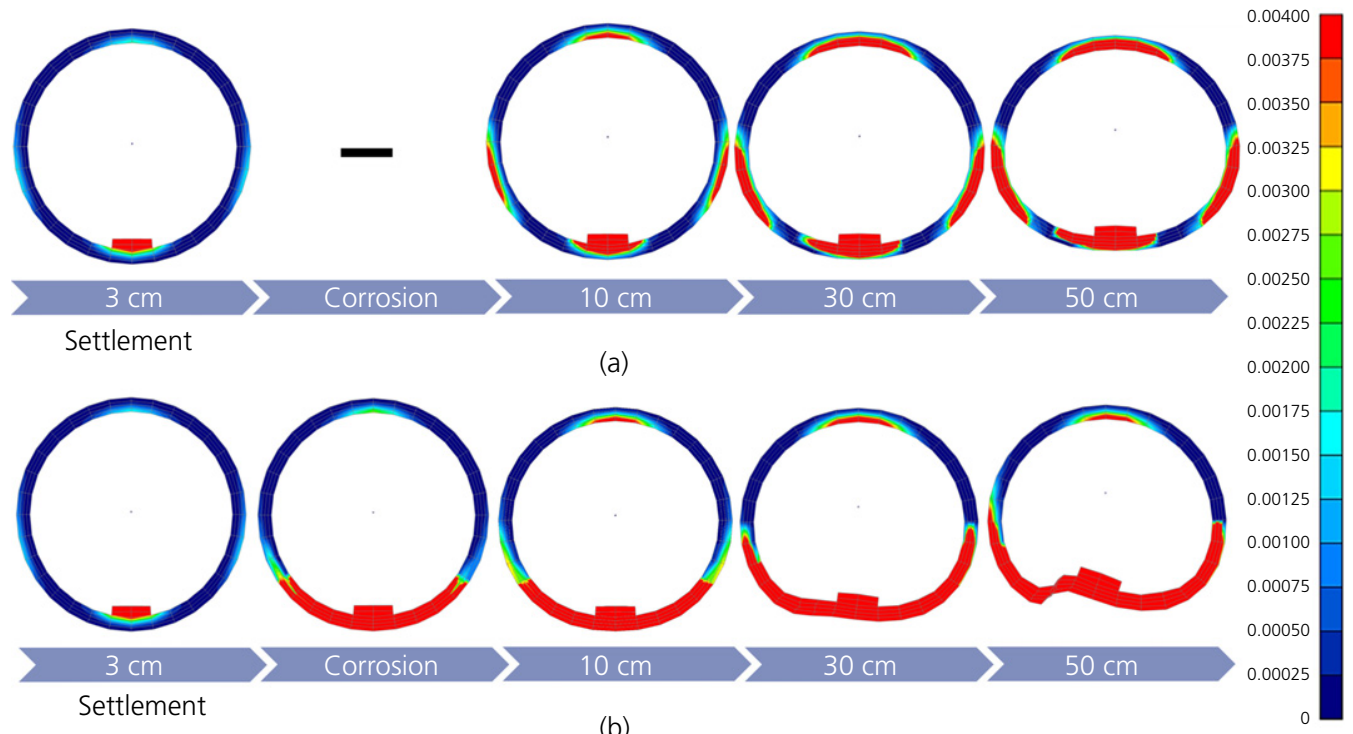

Figure 14. Time series of diagrams showing structure's principal strain distribution and deformation 
failure zone of soil, in this study a sensitivity analysis was conducted relating to the influence of fault displacement on a box culvert. Salt corrosion was applied to the box culvert to evaluate the impact of steel corrosion on the location and direction of the progress of the fault.

\subsection{Numerical modelling}

The structure for analysis is an underground box culvert set on base rock, which addresses on a weak fault area. The entire two-dimensional analytical model and a detailed diagram of the box culvert are shown in Figures 16 and 17, respectively. The analytical model was created with single-layer elements in the depth direction for both the structure and the ground. The physical properties of ground and structure are shown in Tables 7 and 8 , respectively. The structure is composed of RC elements and PL elements. The RC element was constructed in the circumferential ( $X$ - and $Z$-directions) and the axial direction ( $Y$-direction) with a reinforcement rate of $1 \%$, similarly to the actual structure. A softening model in shear strength was adopted for the ground; the model has been proved to be able to simulate the shear failure zone (Maekawa et al., 2003, 2016;

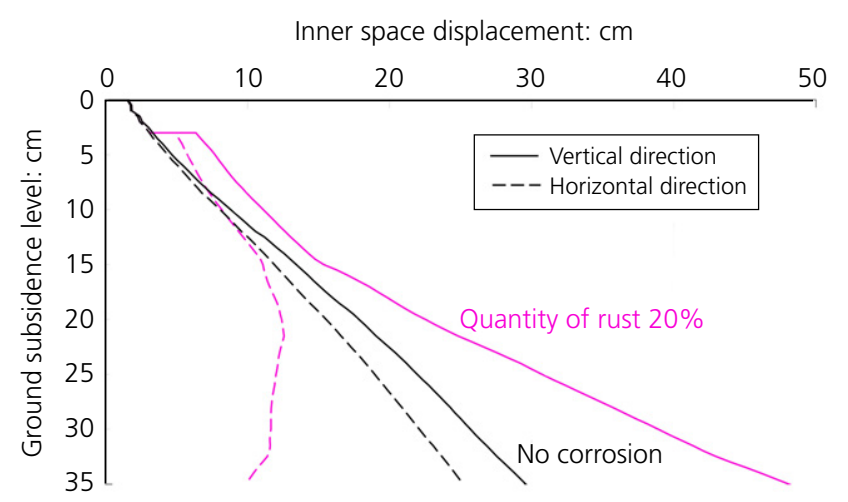

Figure 15. Relationship between forced displacement and the inner space displacement
Soltani and Maekawa, 2015). Here, the width of the shear failure zone was assumed as $5 \mathrm{~mm}$ to identify fracture energy and re-create a localised region that is not dependent on element dimensions.

In addition, a reverse fault with a $45^{\circ}$ dip was pre-set in the initial stage of development. As shown in Figure 16, forced displacement is set along the lateral and bottom boundaries. The point of departure for fault displacement developing throughout the ground is set to the position of $900 \mathrm{~cm}$ in the $X$-direction from the centre. As regards the ground part, the fault plane has not been specified in advance, so the fault slip plane progresses freely while creating a localised region.

The research variable of this numerical analysis is the location of the steel corrosion. As shown in Figure 18, three different corrosion areas were designed, which are located in the left, right and middle of the downside of the box culvert, respectively. In addition, there was also a sound case as the control case. In the same way as the analysis of the circular shield segment, the corrosion rate here was also set as $20 \%$.

\subsection{Analysis result}

Figure 19 shows the distribution of principal strain in the case of a sound box culvert with no corrosion. The shear zone (fault slip plane) accompanying fault displacement progresses toward the middle pillar of the structure and reaches the middle lower part of the structure. Large strain is concentrated in the upper side of the left wall and the bottom of the middle pillar. Even though the deformation is considerably localised, the inner space displacement of the structure is relatively small. The ground above the structure branches out into two or three fault slips.

Figure 20 shows the diagrams of the strain distribution of the corrosion cases. In the case where corrosion was supplied to the lower left part, the fault slip plane progressed toward the

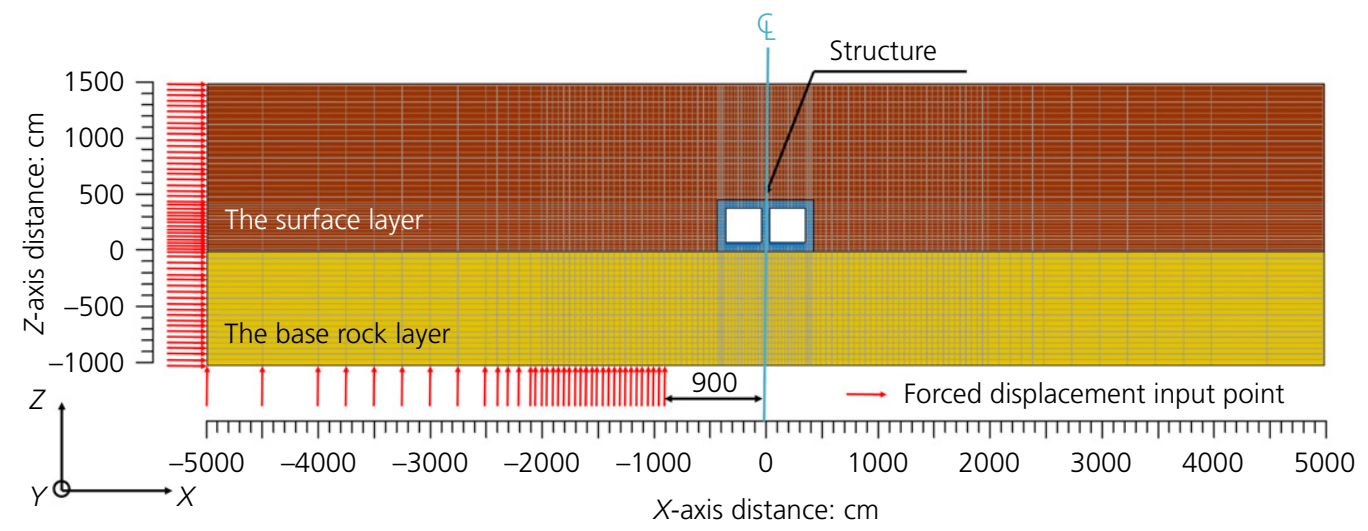

Figure 16. Overall diagram of analytical model (unit: $\mathrm{cm}$ ) 


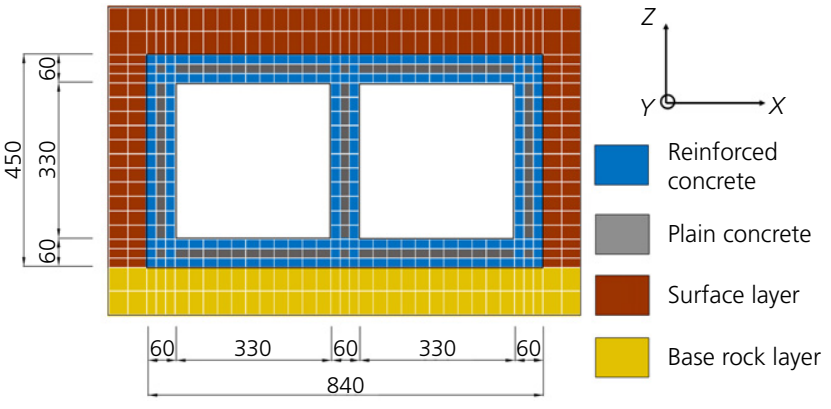

Figure 17. Enlarged diagram of box culvert and periphery duct on the left side of the structure and two lines of fault slip planes formed, originating from the upper left of the structure. In the case where corrosion was supplied to the lower middle part, the fault slip plane branched into two lines, progressing first towards the left side duct centre (boundary of the corrosion region) and next towards the right outer perimeter of the structure. The fault slip plane did not spread toward the fulcrum of the middle lower pillar, but towards the region where deformation can progress easily with corrosion. In the ground above the structure, the fault slip plane branched into four lines and reached the ground surface. In the case where corrosion was supplied to the lower right part, the fault slip

Table 7. Physical properties for numerical analysis of underground ducts subjected to fault displacement (ground)

\begin{tabular}{lccccccc} 
Item & $\begin{array}{c}\text { Initial shear } \\
\text { stiffness: } \mathbf{M P a}\end{array}$ & $\begin{array}{c}\text { Shear } \\
\text { strength: } \mathbf{M P a}\end{array}$ & $\begin{array}{c}\text { Weight per unit } \\
\text { volume: } \mathbf{k g f / \mathbf { c m } ^ { 3 }}\end{array}$ & $\begin{array}{c}\text { Relative } \\
\text { density: \% }\end{array}$ & $\begin{array}{c}\text { Cohesive } \\
\text { strength: } \mathbf{M P a}\end{array}$ & $\begin{array}{c}\text { Friction } \\
\text { angle: } \mathbf{d e g}\end{array}$ & $\begin{array}{c}\text { Shear } \\
\text { zone: } \mathbf{c m}\end{array}$ \\
Surface layer & 63.3 & 0.26 & 0.0018 & 50 & 0.165 & 30 & 0.5 \\
Base rock & 523.0 & 1.79 & 0.0017 & 99.9 & 5 & 35 & 0.5 \\
\hline
\end{tabular}

Table 8. Physical properties for numerical analysis of underground ducts subjected to fault displacement (RC structure)

$\begin{array}{lcccc}\text { Young's modulus: MPa } & \text { Compressive strength: MPa } & \text { Tensile strength: MPa } & \text { Poisson's ratio } & \text { Weight per unit volume: } \mathrm{kgf} / \mathrm{cm}^{\mathbf{3}} \\ 22000 & 30 & 2.6 & 0.2 & 0.0025\end{array}$

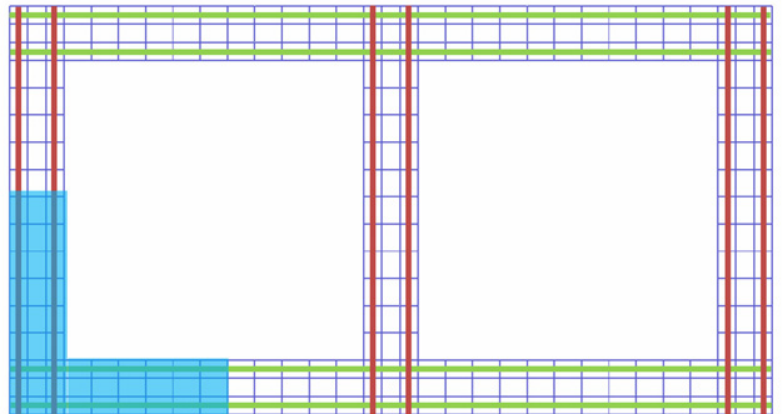

(a)

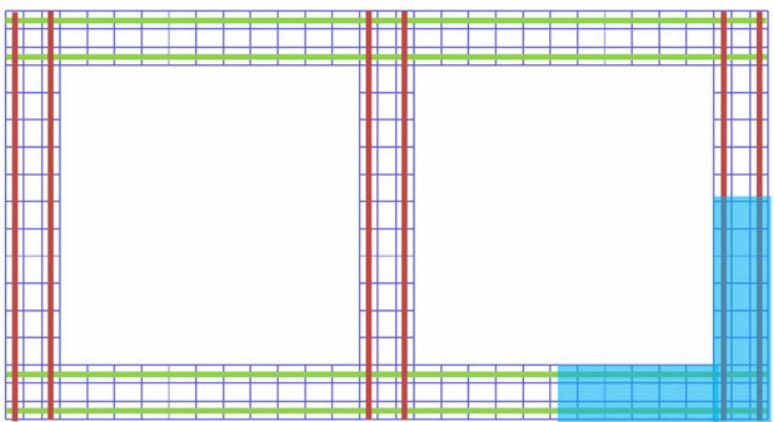

(c)

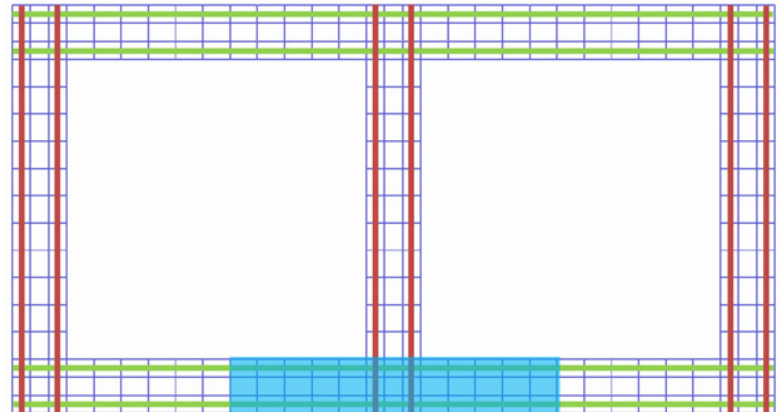

(b)

Figure 18. Relationship between the corrosion areas and reinforcement of the structure: (a) corroded lower left; (b) corroded middle lower part; (c) corroded lower right 

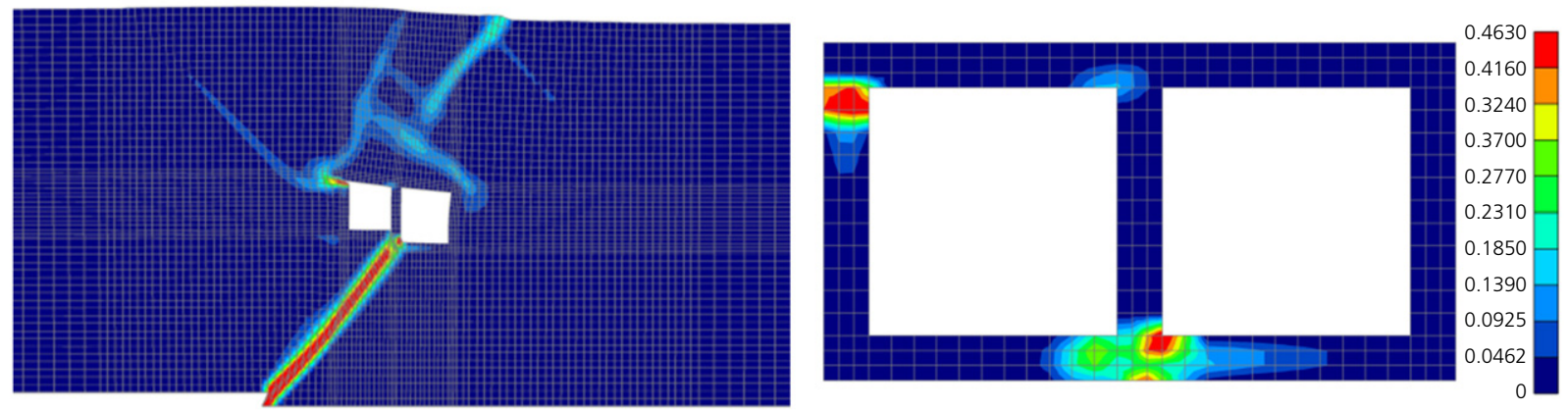

Figure 19. Diagrams showing principal strain distribution and deformation in a sound case
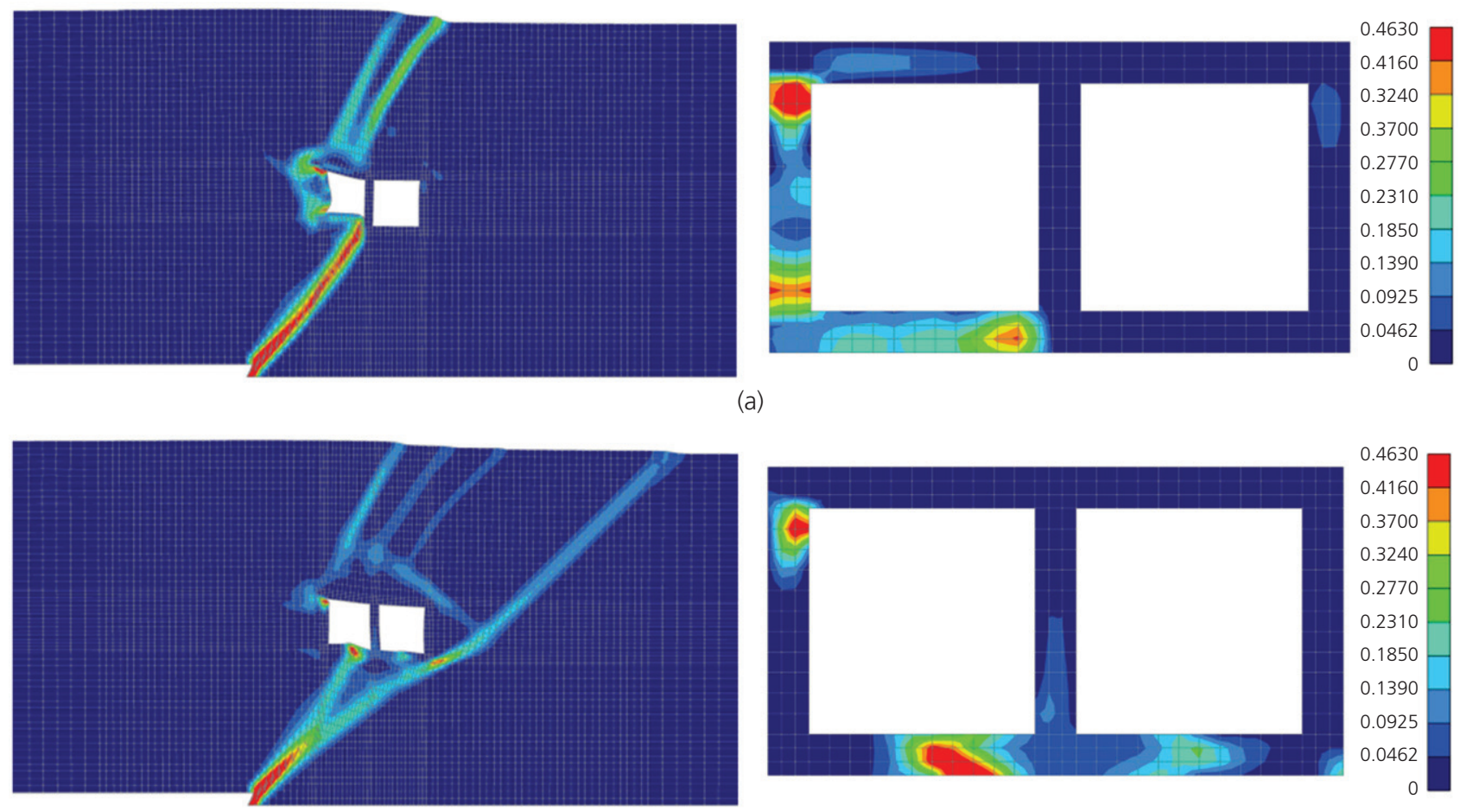

(b)
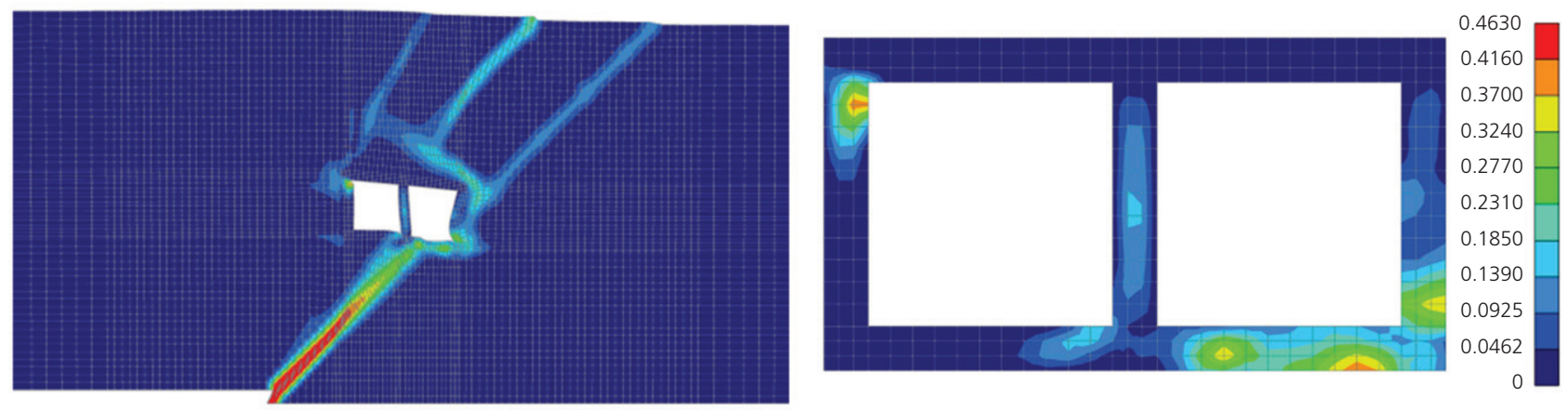

(c)

Figure 20. Diagrams showing principal strain distribution and deformation in a case where corrosion is supplied to the structure: (a) corrosion in lower left part (rate: 20\%); (b) corrosion in middle lower part (rate: 20\%); (c) corrosion in the lower right part (rate: $20 \%$ ) 
plane spread toward the fulcrum of the middle lower pillar. However, because the right-hand side duct deformed easily due to the effects of corrosion, the fault proceeded as if bypassing the outer perimeter on the right side of the structure and branched into three lines to head to the surface.

Based on these results, it is clear that the location of the salt corrosion has a significant impact on the direction of progress of the fault displacement, as well as the failure mode of the structure. When the lower left part of the structure was corroded, the fault displacement was limited to the left side duct and the performance of the right-hand side duct was still maintained. By improving the design and ensuring that there is no impact on the middle pillar, it is possible to avoid the worst case where the entire structure collapses.

\section{Conclusions}

In this study, experiments and simulations considering the interaction between structures and the ground were performed, and the good consistency between them showed the validity of the numerical analysis. Furthermore, two series of numerical analyses to include ground subsidence and fault displacement were performed, and the impact of chloride-induced deterioration on the structure and the surrounding ground was examined. The following conclusions are drawn.

When high lateral earth pressure due to ground subsidence acts on an underground RC tunnel, shear failure may occur on the side of the structure. Also, if material deterioration occurs in the structure, the performance against ground subsidence may reduce.

The impact of chloride-induced deterioration on maintaining functionality of an underground structure is considerable. Such deterioration makes maintenance of the inner space even more difficult, and may reduce the durability of the structure.

The location of corrosion and the failure mode of the structure are intimately related, and decreased rigidity due to damage to the structure changes the deformation properties of the surrounding ground.

It is possible that providing a place where steel is corroded in a structure may prioritise the collapse of that part and not affect the other parts.

In the future, taking both structure-soil interaction and degradation into account, medium scale (1/4) experiments will be conducted. Through these experiments, the impact of salt damage deterioration on the durability of structures will be further specified, and the feasibility of the proposed numerical analysis method will be verified. Based on this research, it is expected that effective countermeasures against structural degradation in consideration of environmental conditions will be proposed.

\section{REFERENCES}

Aoki H, Yamanoi Y, Takahashi H and Maekawa K (2019) Failure mode and safety assessment of corroded RC tunnel sections subjected to subsidence and localised shear of soil foundation. In $3 \mathrm{rd}$ International Conference on Recent Advances in Nonlinear Design, Resilience and Rehabilitation, (CoRASS2019), ) (Barros H, Ferreira C, Adam JM and Delatte N (eds)). Paço das Escolas Coimbra, Portugal.

Castaldo P and De luliis M (2014) Effects of deep excavation on seismic vulnerability of existing reinforced concrete framed structures. Soil Dynamics and Earthquake Engineering 64: 102-112.

Castaldo P, Calvello M and Palazzo B (2013) Probabilistic analysis of excavation-induced damages to existing structures. Computers and Geotechnics 53: 17-30.

Castaldo P, Palazzo B and Mariniello A (2017) Effects of the axial force eccentricity on the time-variant structural reliability of aging r.c. cross-sections subjected to chloride-induced corrosion. Engineering Structures 130: 261-274.

Castaldo P, Gino D and Mancini G (2019) Safety formats for non-linear finite element analysis of reinforced concrete structures: discussion, comparison and proposals. Engineering Structures 193: 136-153.

Castaldo P, Gino D, Bertagnoli G and Mancini G (2020) Resistance model uncertainty in non-linear finite element analyses of cyclically loaded reinforced concrete systems. Engineering Structures 211: 110496, https://doi.org/10.1016/j.engstruct.2020.110496.

Celarec D and Dolšek M (2013) The impact of modelling uncertainties on the seismic performance assessment of reinforced concrete frame buildings. Engineering Structures 52: 340-354.

Funaba S, Kobayashi M, Yamanoi Y and Maekawa K (2018) Interaction between ground with fault displacement and underground box culvert. Japan Society of Civil Engineers 73: 669-670.

Higuchi S, Kato K, Sato S, Ito G and Sato Y (2017) Experimental and numerical study on the characteristics of earth pressure acting on the box-shape underground structure subjected the strike slip fault displacement. Transactions of the Japan Society of Civil Engineers A1: Structure and Earthquake Engineering 73(4): I_19-I_31.

Holický M, Retief JV and Sikora M (2016) Assessment of model uncertainties for structural resistance. Probabilistic Engineering Mechanics 45: 188-197.

Konagai K (2005) Data archives of earthquake-inflicted damage and remedial measures for areas characterized by active foldings. Seisan Kenkyu 57(6): 507-513.

Maekawa K and Fukuura N (2013) Nonlinear modeling of 3D structural reinforced concrete and seismic performance assessment. In Infrastructure Systems for Nuclear Energy (Hsu TTC, Wu CL and Lin JL (eds)). John Wiley \& Sons, Ltd, Chichester, UK, pp. $153-184$.

Maekawa K, Pimanmas A and Okamura H (2003) Nonlinear Mechanics of Reinforced Concrete. Spon Press, London, UK.

Maekawa K, Zhu X, Chijiwa N and Tanabe S (2016) Mechanism of long-term excessive deformation and delayed shear failure of underground RC box culverts. Journal of Advanced Concrete Technology 14(5): 183-204.

Mori M (2013) Research trend on structural safety of tunnels. National Agriculture and Food Research Organization, Kannondai, Tsukuba, Ibaraki, Japan, Technical report of the National Institute for Rural Engineering 214: 31-76.

Oka S (2015) Case of inner space deformation and steel corrosion in shielded electric power cable service tunnel. JEPOC Journal 379: 53-56. 
Omachi T (2000) On damage in Taiwan due to the 1990 Chichi earthquake. Journal of Japan Society of Dam Engineers 10(2): $138-150$.

Otsuka H, Aibe T and Soejima S (2012) Study on the effectiveness of earthquake-resistant joint against seismic displacement in underground structure. Transactions of the Japan Society of Civil Engineers A1: Structural and Earthquake Engineering 68(4): I_253-I_259.

Sakashita K and Hata A (2019) Analytical study on behaviour of RC box culvert subjected to fault displacement. Journal of Japan Society of Civil Engineers A1: Structural and Earthquake Engineering 75(4): I_73-I_80.

Sakurai T (1990) A report on the earthquake fault appearing in the Tanna tunnel under construction by North-Izu earthquake 1930 . Journal of the Japan Society of Engineering Geology 39(6): 540-544.
Soltani M and Maekawa K (2015) Numerical simulation of progressive shear localisation and scale effect in cohesionless soil media. International Journal of Non-Linear Mechanics 69: 1-13.

Toongoenthong K and Maekawa K (2005) Multi-mechanical approach to structural performance assessment of corroded RC members in shear. Journal of Advanced Concrete Technology 3(1): $107-122$.

Towhata I and Ishihara K (1985) Modeling soil behaviours under principal stress axes rotation. Proceedings of the 5th International Conference on Numerical Method in Geotechnics, Nagoya, Japan, pp. 523-530.

Yamazaki T, Ariizumi T and Igarashi H (2004) Series lecture Introduction to ground deformation due to shield excavation (14) towards a new era of shield (Part 2). New Technical Issues in Maintenance and Management - Tunnel and Underground 35(1): 65-71.

\section{How can you contribute?}

To discuss this paper, please email up to 500 words to the editor at journals@ice.org.uk. Your contribution will be forwarded to the author(s) for a reply and, if considered appropriate by the editorial board, it will be published as discussion in a future issue of the journal.

Proceedings journals rely entirely on contributions from the civil engineering profession (and allied disciplines). Information about how to submit your paper online is available at www.icevirtuallibrary.com/page/authors, where you will also find detailed author guidelines. 